University of Rhode Island

DigitalCommons@URI

The Rhode Island Current Conditions Index

Economics

$1-2020$

\title{
Rhode Island Current Conditions Index - January 2020
}

Leonard Lardaro

URI Department of Economics, lardaro@uri.edu

Follow this and additional works at: https://digitalcommons.uri.edu/ricci

Part of the Econometrics Commons

Terms of Use

All rights reserved under copyright.

\section{Recommended Citation}

Lardaro, Leonard, "Rhode Island Current Conditions Index -- January 2020" (2020). The Rhode Island Current Conditions Index. Paper 194.

https://digitalcommons.uri.edu/ricci/194

This Newsletter is brought to you for free and open access by the Economics at DigitalCommons@URI. It has been accepted for inclusion in The Rhode Island Current Conditions Index by an authorized administrator of DigitalCommons@URI.For more information, please contact digitalcommons-group@uri.edu. 


\title{
CURRENT CONDITIONS
}

\section{LEONARD LARDARO, URI}

\author{
Available Online: http: / www.Ilardaro.com/current.htm \\ Twitter: @ladardo
}

VOL XXVII

NUMBER 2

JAN 2020

What a difference a month makes! In last month's report, based on data that was not yet revised, I began by stating: What a way to end the year! Rhode Island's December performance was its best by far for all of 2019. At 92, the December Current Conditions Index value was its highest since June of 2018. Wow was that far off from what revisions show.

While prior levels of payroll employment were not revised lower as I had feared, one key indicator, Employment Service Jobs, a leading labor market indicator that was thought to have risen every month last year actually fell for all of 2019. Ditto for January of 2020. This indicator, which is a leading indicator of future employment, even then was signaling weakening job gains in 2020. As I write this (mid-March), that's actually an incredible understatement. At any rate, incorporating the updated labor market data, the Current Conditions Index for all of 2019 was revised lower for nine months, higher for one, and unchanged for two. Worse yet, for four months last year, the CCI was at its neutral value of 50 while in four other months, the CCI managed to climb to only 58, barely above neutral. So, 2019 was not a terribly strong year for Rhode Island's economy. It is clear that as I write this, Rhode Island has entered into the early stages of a recession that is also affecting the US and global economies. Rhode Island therefore finds itself entering this recession from a relatively weak position. If there is good

\begin{tabular}{|l|r|r|}
\hline \multicolumn{3}{|c|}{ CCI Indicators - \% Change } \\
\hline Government Employment & 1.5 & $\mathbf{Y}$ \\
\hline US Consumer Sentiment & 9.7 & Y \\
\hline Single-Unit Permits & 41.6 & Y \\
\hline Retail Sales & 10.5 & Y \\
\hline Employment Services Jobs & -5.2 & \\
\hline Priv. Serv-Prod Employment & 0.5 & Y \\
\hline Total Manufacturing Hours & -3.8 & \\
\hline Manufacturing Wage & -2.3 & \\
\hline Labor Force & 0.5 & $\mathbf{Y}$ \\
\hline Benefit Exhaustions & -20.1 & Y \\
\hline New Claims & -17.1 & Y \\
\hline Unemployment Rate (change) & -0.3 & Y \\
\hline \multicolumn{2}{|c|}{ Y = Improved Value } \\
\hline
\end{tabular}

news, although Rhode Island's economy is FILO, the FI (First In) does not apply this time, given the abruptness of the decline in global economic activity. Sadly though, our status as LO (Last Out) remains entirely in tact, highlighted by our state's disappointing 2019 economic performance.

Rhode Island's elected officials, whom I absolutely refuse to refer to as leaders, have for years hidden behind an exceptionally misleading (i.e., noisy) statistic: our Unemployment Rate. Their implication about our dramatically reduced rate has always been that our jobless rate declined from double digits for all the usual reasons, most notably robust job growth. Welcome to Rhode Island. Unbeknown to almost anyone in this state, resident employment, the number of employed Rhode Islanders,

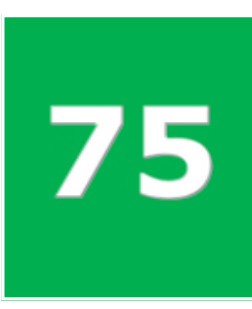

\begin{tabular}{|c|c|c|c|c|} 
& Jan & Feb & Mar & Apr \\
\hline 2019 & $58 \downarrow$ & $50 \uparrow$ & 58 & $50 \downarrow$ \\
\hline 2020 & 75 & & & \\
\hline
\end{tabular}

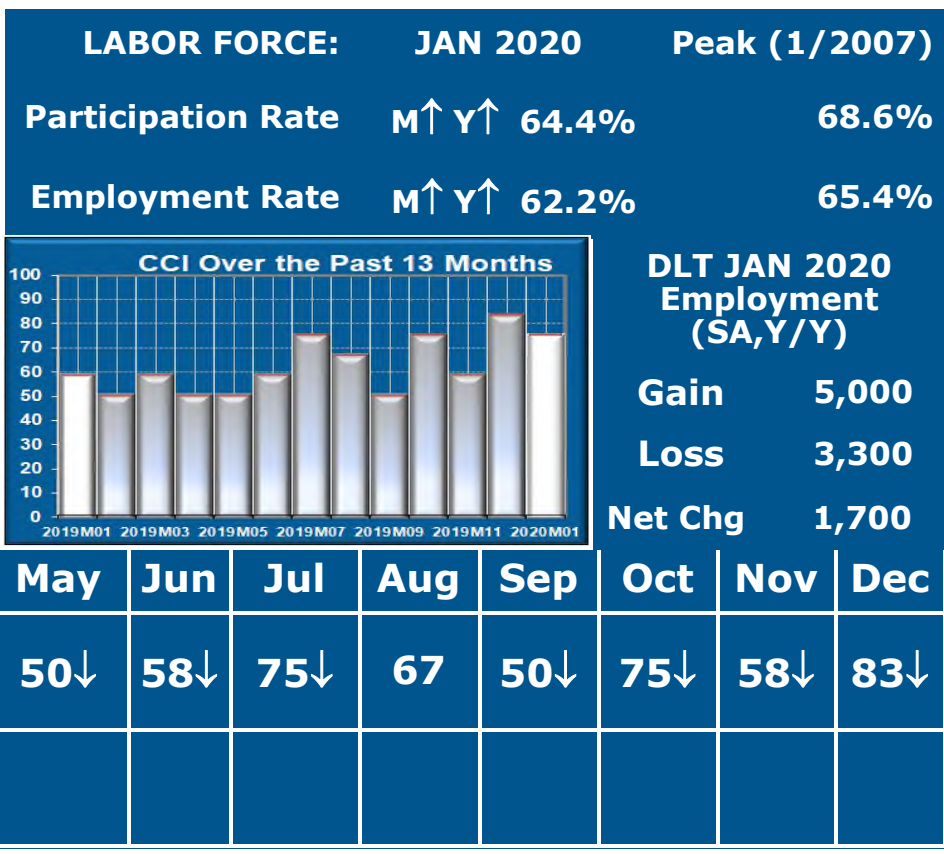

the measure directly linked to the Unemployment Rate, has grown during the last recovery (get used to that) but as of our entry into the current recession, it remains below its value in 2006 ! How, then could such lukewarm employment growth have translated into dramatic declines in our jobless rate? Simple: Rhode Island's Labor Force has been declining for close to a decade, a phenomenon I refer to as a "train wreck." The secular decline only ended in early 2017 . Even with the recent increases, our Labor Force remains far below its prior peak (in June 2010).

How much has weak job growth combined with a diminished labor force impacted our Unemployment Rate? If our labor force participation rate had remained at its average from the post-financial crisis recovery (around 67\%), then using current population and employment rate values, the January 2020 Unemployment Rate would have been 7.7 percent. And that's based on U3.

The strength of Rhode Island's recovery has been overstated in a very clever way by our state's elected officials for years. The reality is that the last recovery (that just ended) was not as strong as people were led to believe (by inference). Many Rhode Islanders have either been left behind our never managed to catch up. Now that a recession of uncertain magnitude and duration has begun, it is appropriate to refer to the old saying about the tide going out. The shallowness of the last recovery will become apparent very quickly, not so much in the magnitude, that is largely out of anyone's control, but in terms of our ability to move into an eventual recovery.

As for individual January performances, all of these are now meaningless. Ironically, New Claims for January were sharply lower. As of mid-March, they have grown in the twenty percent plus range based on mass layoffs on a not seasonally adjusted basis. I'm afraid to contemplate how much the seasonally adjusted value surged. Fasten your seat belts. This is going to get ugly. When it is over, we will not be returning to things as they were. Hopefully that will also pertain to state government. The $120+$ legislative days devoted to the PawSox will haunt us

Copyright ( ) 2018, 2019 Leonard Lardaro, Ph.D. All rights reserved. 